\title{
Serum Adiponectin, Resistin Levels and Non-alcoholic Fatty Liver Disease in Obese Children
}

\author{
Chao Chun ZOU, Li LiAng, FAng HONG, Jun Feng FU and Zheng Yan ZHAO \\ Department of Endocrinology, The Children's Hospital of Zhejiang University School of Medicine, 57 Zhugan Xiang, Hangzhou \\ 310003, China
}

\begin{abstract}
The objective is to investigate the relation between the levels of two serum adipocytokines (adiponectin and resistin) and non-alcoholic fatty liver disease (NAFLD) in obese children. In this study, 113 obese children were enrolled and divided into 3 groups. Obese group 1 was defined as obese children without any liver abnormality. Obese group 2 was defined as obese children just with fatty infiltration of the liver in ultrasonic appearance and obese group 3 was defined as obese children with liver function abnormality. The controls consisted of 37 nonobese children without endocrine, metabolic or kidney disease. The levels of serum adiponectin and resistin were measured by ELISA method. Insulin resistance by homeostasis model (HOMA-IR), area under curve of glucose (AUCG), serum total cholesterol, triglyceride, alanine aminotransferase, uric acid, HDL-cholesterol, LDL-cholesterol and body mass index (BMI) were measured as well. In obese children, NAFLD were found in 63 cases $(55.75 \%)$. Serum adiponectin levels of obese children were significantly lower than that of controls (3.63 vs $5.79 \mu \mathrm{g} / \mathrm{mL}, P<0.001)$ while serum resistin levels were not different $(P=0.876)$. Moreover, serum adiponectin levels in obese group 1 were significantly higher than that of group 2 and 3 (4.24 vs 3.37 and $3.12 \mu \mathrm{g} / \mathrm{mL}$, all $P<0.05)$ and no difference was found between obese group 2 and obese group 3 $(P>0.05)$. Serum resistin levels among the three obese groups were $4.37 \mathrm{ng} / \mathrm{mL}, 3.72 \mathrm{ng} / \mathrm{mL}$ and $4.24 \mathrm{ng} / \mathrm{mL}$ without significant difference $(P=0.592)$. NAFLD, BMI, gender and HDL-cholesterol were independent determinants of serum adiponectin levels in children analyzed by multiple regression analysis, which explained $33 \%$ of the variance. Serum adiponectin levels were inversely associated with BMI, gender and NAFLD (all $P<0.05$ ) and were positively associated with HDL-cholesterol levels $(P=0.033)$. These results suggest that adiponectin might be a protective factor in NAFLD occurrence in obese children, and that the measurement of adiponectin should be part of the standard evaluation of the obese child and may help to evaluate the occurrence of NAFLD.
\end{abstract}

Key words: Adiponectin, Resistin, Non-alcoholic fatty liver disease (NAFLD), Obesity, Child

(Endocrine Journal 52: 519-524, 2005)

NONALCOHOLIC fatty liver disease (NAFLD) is a clinicopathologic syndrome that encompasses several clinical entities. The spectrum of conditions ranges from simple steatosis to steatohepatitis (NASH), fibrosis and end stage liver disease [1-3]. The condition was originally described in diabetic, middle-aged females without a history of significant alcohol use with liver histology consistent with alcoholic hepatitis. NAFLD is now recognized as the most common cause

Received: January 5, 2005

Accepted: June 3, 2005

Correspondence to: Dr. Li LIANG, Department of endocrinology, The Children's Hospital of Zhejiang University School of Medicine, 57 Zhugan Xiang, Hangzhou 310003, China of liver disease in pediatrics, paralleling the rapid rise in prevalence of obesity in children globally. As no specific therapy has been approved for this condition and it may progress even after weight loss, the study of its mechanisms is very important to prevent the occurrence of NAFLD. Recent studies suggest that insulin resistance and oxidative stress might be involved in the pathogenesis [4-6].

Adiponectin and resistin are recently described as secretory products of adipose tissue. Adiponectin is secreted by fat cells and circulates in the blood and is the most abundant gene product in fat tissue. In contrast to all other known adipocytokines, adiponectin levels are known to be decreased in individuals with either type 2 diabetes or coronary artery disease [7, 8]. Recent stud- 
ies also found lower serum adiponectin levels in obese adults, even in obese children $[9,10]$, but whether adiponectin is related with NAFLD is still unclear. Animal model also showed another adipocytokine, resistin being associated with diet-induced obese $[11,12]$. However, the role of resistin in the pathophysiology of human obesity is controversial [13-15].

Here, we measured serum adiponectin and resistin levels in obese and nonobese children to study their role in obesity, especially in the mechanism of NAFLD.

\section{Subjects and Methods}

\section{Subjects}

A total of 113 obese children, according to the criteria that a child was considered to be obese when the body weight exceeded $120 \%$ of the standard body weight (defined as the mean body weight corresponding to the height for that age obtained from national statistics for Chinese school children in 1995), were consecutively enrolled in the study. The ages of the subjects ranged from 6.00 to 16.75 years (mean $11.05 \pm 2.31$ years). They were divided into 3 groups. Obese group 1 was defined as obese children without any liver abnormality, and included 32 boys and 18 girls with a mean age of $10.75 \pm 2.10$ years. Obese group 2 was defined as obese children just with fatty infiltration of the liver in ultrasonic appearance, but without liver function abnormality, and included 14 boys and 8 girls with a mean age of $11.63 \pm 2.29$ years. Obese group 3 was defined as obese children with liver function abnormality, and included 32 boys and 9 girls with a mean age of $11.10 \pm 2.55$ years. The control group consisted of 37 nonobese children without endocrine, metabolic or kidney disease, and included 17 boys and 20 girls with a mean age of $10.3 \pm 1.78$ years (7.25-14.91 years). All subjects had no history of alcohol abuse and the results of tests for hepatitis virus and TORCH were negative.

The Human Study Committee of the Children's Hospital of Zhejiang University approved this study. Informed consent was obtained either from each subject or from his or her parents as appropriate.

\section{Adiponectin and Resistin Measurement}

All sera were stored frozen at $-80^{\circ} \mathrm{C}$ until measure- ment. The sera were diluted by 100 and 5 -fold for total adiponectin and resistin measurement before assay. Serum levels of adiponectin and resistin were all assayed by an enzyme linked immunosorbent assay (ELISA). Quantikine kits purchased form R\&D Systems Incorporation (USA) were used to detect serum adiponectin and resistin according to the manufacturer's protocol. Negative and positive controls were used. The intra- and interassay CVs of adiponectin ranged from $2.5 \%$ to $4.7 \%$ and $5.8 \%$ to $6.9 \%$, respectively. The intra- and interassay CVs of resistin ranged from $3.8 \%$ to $5.3 \%$ and $7.8 \%$ to $9.2 \%$, respectively. The assay sensitivities ranged from $0.079-0.891 \mathrm{ng} / \mathrm{mL}$ $(0.246 \mathrm{ng} / \mathrm{mL})$ for adiponectin and $0.010-0.055 \mathrm{ng} / \mathrm{mL}$ $(0.026 \mathrm{ng} / \mathrm{mL})$ for resistin.

\section{Biochemical Measurements}

Oral glucose tolerance tests (OGTTs) were used in the assessment of insulin sensitivity and insulin secretion. Plasma glucose levels were detected by glucose oxidase method (Beijing North Biotechnology Company, China) with intra-assay and interassay $\mathrm{CVs}$ of $2.1 \%$ and $4.4 \%$. Insulin serum levels were determined by radioimmunoassay (Beijing North Biotechnology Company, China). The intra-assay and interassay CVs were $6.4 \%$ and $9.7 \%$, respectively. Insulin resistance by homeostasis model (HOMA-IR) and area under curve of glucose (AUCG) were calculated.

Serum total cholesterol (TC), triglyceride (TG), alanine aminotransferase (ALT), and uric acid were measured in the clinical laboratories of our unit. Plasma HDL-cholesterol (HDL-C) and LDL-cholesterol (LDL-C) levels were detected in the Central Laboratory of Radioimmunity in Hangzhou.

\section{Statistics}

Statistical analyses were conducted by using SPSS software (version 10.0). Pearson chi-square was used to measure the enumeration data between subgroups. Quantitative data were presented as mean $\pm \mathrm{SD}$. Because the data for adiponectin, resistin, TG, ALT, and insulin were skewed, they were transformed logarithmically before performing a statistical analysis and being presented as mean. The statistical significance between means was estimated by one-way ANOVA followed by LSD multiple comparisons or an unpaired Student's t test where appropriate. Stepwise multiple 
linear regression models were used to examine the determinant of serum adiponectin or resistin levels. Differences were considered statistically significant at $P<0.05$.

\section{Results}

The characteristics of controls and obese children are shown in Table 1. Compared with controls, higher serum TC, TG, ALT, HDL-C, uric acid, baseline fasting insulin, 2h-glucose, AUCG, HOMA-IR and lower
LDL-C were found in obese children (all $P<0.005$ ). Moreover, the adiponectin level in obese children was $3.63 \mu \mathrm{g} / \mathrm{mL}$, which was significantly lower than that of controls $(5.79 \mu \mathrm{g} / \mathrm{mL}, P<0.001)$. However, the serum resistin levels were not different between obese children and controls $(4.25 \mathrm{ng} / \mathrm{mL}$ vs $4.18 \mathrm{ng} / \mathrm{mL}$, $P=0.876$ ).

In all the 113 obese children, NAFLD was found in 63 cases $(55.75 \%)$, including 22 cases $(19.47 \%)$ in obese group 2 and 41 cases (36.28\%) in obese group 3 . The characteristics of these three groups are shown in Table 2. Age, gender, and sex development were not

Table 1. Characteristics of obese group and controls

\begin{tabular}{lcccc}
\hline & Controls $(\mathrm{n}=37)$ & Obese group $(\mathrm{n}=113)$ & $\chi^{2} / \mathrm{t}$ & $P$ value \\
\hline Female/Male & $20 / 17$ & $35 / 78$ & 6.390 & 0.011 \\
Prepuberty/puberty & $25 / 12$ & $55 / 58$ & 3.998 & 0.046 \\
Age (Year) & $10.03 \pm 1.78$ & $11.05 \pm 2.31$ & 2.460 & 0.015 \\
& $(7.25-14.91)$ & $(6.00-16.75)$ & & \\
BMI $\left(\mathrm{kg} / \mathrm{m}^{2}\right)$ & $15.52 \pm 1.53$ & $27.71 \pm 3.88$ & 7.54 & $<0.001$ \\
log(ALT) & $1.21 \pm 0.15$ & $1.62 \pm 0.33$ & 5.704 & $<0.001$ \\
HDL-C $(\mathrm{mmol} / \mathrm{L})$ & $1.30 \pm 0.33$ & $0.99 \pm 0.31$ & 4.327 & $<0.001$ \\
LDL-C $(\mathrm{mmol} / \mathrm{L})$ & $2.05 \pm 0.46$ & $2.47 \pm 0.67$ & 3.143 & $<0.001$ \\
TC $(\mathrm{mmol} / \mathrm{L})$ & $3.68 \pm 0.68$ & $2.16 \pm 0.84$ & 7.782 & $<.002$ \\
TG $(\mathrm{mmol} / \mathrm{L})$ & $1.15 \pm 0.64$ & $361.19 \pm 83.10$ & 8.410 & $<0.001$ \\
Uric acid $(\mu \mathrm{mol} / \mathrm{L})$ & $264.17 \pm 50.58$ & $12.87 \pm 9.02$ & 7.307 & $<0.001$ \\
Baseline fasting insulin $(\mu \mathrm{IU} / \mathrm{mL})$ & $6.33 \pm 1.65$ & $1.03 \pm 0.25$ & 8.379 & $<0.001$ \\
$\log (\mathrm{Insulin})$ & $0.79 \pm 0.11$ & $5.94 \pm 1.31$ & 2.661 & 0.009 \\
2h-glucose $(\mathrm{mmol} / \mathrm{L})$ & $5.33 \pm 0.83$ & $18.30 \pm 2.83$ & 5.635 & $<0.001$ \\
AUCG & $15.99 \pm 1.74$ & $2.65 \pm 1.95$ & 7.128 & $<0.001$ \\
HOMA-IR & $1.27 \pm 0.37$ & 3.63 & 5.305 & $<0.001$ \\
Adiponectin $(\mu \mathrm{g} / \mathrm{mL})$ & 5.79 & 4.18 & 0.156 & 0.876 \\
Resistin $(\mathrm{ng} / \mathrm{mL})$ & 4.25 & & & \\
\hline
\end{tabular}

Table 2. Characteristics of different obese groups

\begin{tabular}{|c|c|c|c|c|c|c|}
\hline & Obese group1 & Obese group2 & Obese group3 & LSD & $\chi^{2 / F}$ & $P$ value \\
\hline Number & 50 & 22 & 41 & & & \\
\hline Female/Male & $18 / 32$ & $8 / 14$ & $9 / 32$ & & 2.452 & 0.294 \\
\hline Prepuberty/Puberty & $27 / 23$ & $7 / 15$ & $21 / 20$ & & 3.176 & 0.204 \\
\hline Age (Year) & $\begin{array}{c}10.75 \pm 2.10 \\
(7.25-16.75)\end{array}$ & $\begin{array}{c}11.63 \pm 2.29 \\
(7.58-16.00)\end{array}$ & $\begin{array}{c}11.10 \pm 2.55 \\
(6.00-16.30)\end{array}$ & & 1.144 & 0.322 \\
\hline BMI $\left(\mathrm{kg} / \mathrm{m}^{2}\right)$ & $26.21 \pm 3.45$ & $28.57 \pm 3.84$ & $29.08 \pm 3.83$ & 1 vs 2,3 & 7.643 & 0.001 \\
\hline $\log (\mathrm{ALT})$ & $1.41 \pm 0.15$ & $1.47 \pm 0.15$ & $1.98 \pm 0.27$ & 3 vs 1,2 & 101.52 & $<0.001$ \\
\hline Uric acid & $341.45 \pm 75.50$ & $342.46 \pm 55.61$ & $394.26 \pm 93.38$ & 3 vs 1,2 & 5.450 & 0.006 \\
\hline $\mathrm{HDL}-\mathrm{C}(\mathrm{mmol} / \mathrm{L})$ & $0.99 \pm 0.30$ & $1.00 \pm 0.30$ & $0.97 \pm 0.33$ & & 0.080 & 0.923 \\
\hline LDL-C (mmol/L) & $2.41 \pm 0.80$ & $2.58 \pm 0.65$ & $2.49 \pm 0.51$ & & 0.511 & 0.602 \\
\hline $\mathrm{TC}(\mathrm{mmol} / \mathrm{L})$ & $4.10 \pm 0.94$ & $4.29 \pm 0.84$ & $4.16 \pm 0.72$ & & 0.401 & 0.670 \\
\hline $\mathrm{TG}(\mathrm{mmol} / \mathrm{L})$ & $2.44 \pm 1.44$ & $2.47 \pm 1.29$ & $2.54 \pm 1.51$ & & 0.045 & 0.940 \\
\hline $\log ($ Insulin $)$ & $0.99 \pm 0.24$ & $1.12 \pm 0.24$ & $1.04 \pm 0.25$ & 1 vs 2 & 2.364 & 0.099 \\
\hline $2 \mathrm{~h}$-glucose $(\mathrm{mmol} / \mathrm{L})$ & $6.00 \pm 1.04$ & $5.72 \pm 1.04$ & $5.99 \pm 1.68$ & & 0.393 & 0.676 \\
\hline AUCG & $18.10 \pm 2.62$ & $17.79 \pm 2.36$ & $18.78 \pm 3.23$ & & 1.009 & 0.368 \\
\hline $\log ($ HOMA-IR) & $0.30 \pm 0.26$ & $0.43 \pm 0.23$ & $0.34 \pm 0.26$ & 1 vs 2 & 2.030 & 0.136 \\
\hline Resistin (ng/mL) & 4.37 & 3.72 & 4.24 & & 0.529 & 0.592 \\
\hline Adiponectin $(\mu \mathrm{g} / \mathrm{mL})$ & 4.24 & 3.37 & 3.12 & 1 vs 2,3 & 5.717 & 0.004 \\
\hline
\end{tabular}


Table 3. Multiple linear regression analysis for determinant of serum adiponectin levels in children

\begin{tabular}{lcrcc}
\hline & $\mathrm{B}$ & $\mathrm{t}$ & $P$ value & $\mathrm{R}^{2}$ \\
\hline Constant & 2.004 & 17.273 & $<0.001$ & \\
BMI & -0.0126 & 3.937 & $<0.001$ & \\
Gender & -0.0889 & 2.666 & 0.009 & \\
NAFLD & -0.0506 & 2.411 & 0.017 & \\
HDL-C & 0.110 & 2.155 & 0.033 & 0.337 \\
\hline
\end{tabular}

significantly different (all $P>0.005$ ). Serum ALT and uric acid in obese group 3 were significantly higher than those of obese group 1 and 2 (all $P<0.005$ ). BMI in obese group 1 was significantly lower than that of group 2 and $3(P<0.05)$. Serum adiponectin levels in obese group 1 were significantly higher than those of group 2 and $3(4.24 \mu \mathrm{g} / \mathrm{mL}$ vs $3.37 \mu \mathrm{g} / \mathrm{mL}$ and $3.12 \mu \mathrm{g} /$ $\mathrm{mL}$, all $P<0.005)$ and no difference was found between obese group 2 and obese group $3(P>0.05)$. Serum resistin levels among the three obese groups were $4.37 \mathrm{ng} / \mathrm{mL}, 3.72 \mathrm{ng} / \mathrm{mL}$ and $4.24 \mathrm{ng} / \mathrm{mL}$ without significant difference $(P=0.592)$. Other biochemical markers, such as HDL-C, LDL-C, TC, TG, baseline fasting insulin, 2h-glucose, AUCG, and HOMA-IR were not different among these three groups (all $P>0.05$ ).

Stepwise multiple regression analysis in this study included age, gender (treated female as 0 , male as 1), BMI, sex development (treated prepuberty as 1 , puberty as 2), uric acid, TG, HDL-C, LDL-C, AUCG, log (HOMA-IR), log (resistin) and NAFLD (treat children without NALFD as 1, obese group 2 as 2 and obese group 3 as 3). Gender, BMI, NAFLD, and HDL-C were the independent determinants of serum adiponectin levels in children, which explained $33.7 \%$ of the variance. Serum adiponectin levels were inversely associated with BMI, gender and NAFLD $(P<0.001$, $P=0.009$ and $P=0.017$ respectively) and were positively associated with HDL-C levels $(P=0.033)$. Age, sex development, AUCG, log (resistin), serum TG, LDL-C, and uric acid were excluded in the equations (all $P>0.05$ ), as shown in Table 3 .

\section{Discussion}

Until recently, NAFLD was considered to be rare in children. It is now recognized as an important pediatric liver disease, especially because pediatric obesity is much more common worldwide. Children with NAFLD may present as young as 4 years old and fibrosis is often found in liver biopsy and cirrhosis has been reported $[16,17]$. In the present study, NAFLD was found in $55.75 \%$ of obese children with a mean age of $11.32 \pm 2.49$ years $(6.00-16.75$ years). Although most of the obese children with NAFLD were male $(46 / 63,73.02 \%)$, it was not significantly different from the obese children without liver abnormality $\left(18 / 32\right.$ vs $\left.17 / 46, \chi^{2}=3.184, P=0.074\right)$. This implied that the male is apt to obesity and NAFLD, which is consistent with other reports [18].

In this data, we noted lower adiponectin level in obese children, which is consistent with previous studies [10]. Animal model and some human studies have shown that resistin may be associated with dietinduced obesity [11-13]. However, the resistin in obese children in this study was not different from that of the controls. This is similar to previous reports and suggests adiponectin, not resistin, plays a role in obesity $[14,15]$.

Some studies suggest that insulin resistance and oxidative stress might be involved in the pathogenesis of NAFLD $[5,6]$. We here seek to describe the relation between the two serum adipocytokines (adiponectin and resistin) and NAFLD in obese children. To our knowledge, this is the first study on the relationship of serum adiponectin and resistin levels to NAFLD in obese children. We found that obese children with NALFD had lower serum adiponectin levels than obese children without liver abnormality. Moreover, NAFLD occurrence was an independent factor of serum adiponectin levels in children by stepwise multiple regression analysis. This suggested that adiponectin, as an adipocytokine, might play role in the occurrence of NAFLD.

Although many studies have been done on NAFLD in obese children, the mechanism is not clear. Some studies have suggested that NAFLD in obese children might stem either from genetic defects or excessive calorie intake, and that the progression of NAFLD may be the result of an imbalance between proinflammatory and anti-inflammatory cytokines, triggering the formation of reactive oxygen species and intrahepatic lipid peroxidation [20-23]. Some adipocytokines (leptin, TNF- $\alpha$ ) have been traditionally thought to be involved in the inflammatory process [24-26]. So we postulated that adiponectin might play an important role in this condition as a protective factor through 
stimulating fatty acid oxidation, decreasing plasma TG, and improving glucose metabolism by increasing insulin sensitivity. The fact that pro-inflammatory and anti-inflammatory cytokines take part in this condition may be the reason that NAFLD might progress even after weight loss [27]. We also found serum adiponectin levels were positively associated with HDL-C levels, which have been reported to be lower in NALFD [28], but the precise relationship of adiponectin to HDL-C is unclear.

Recent studies found that circulating adiponectin is predominantly present as several characteristic multimers, including low molecular weight adiponectin (LMW form) comprising the basic unit of trimer, middle molecular weight adiponectin (MMW form) comprising 2 subunits of trimer, and high molecular weight adiponectin (LMW form) comprising 12-18 subunits [29, 30]. Moreover, different forms of adiponectin might activate different signal transduction pathways and exert distinct functions on its target tissue [31-33]. Pajvani et al. reported that HMW complex is the most active form of adiponectin in depressing blood glucose levels [33]. In the present study, although no significant difference of total serum adiponectin between the obese group 2 and 3 was found, whether different ratio of the different forms (HMV, MMV or LMV form) which might exist have an influence on these groups is still unknown, hence further study is required.

It is important to acknowledge the limitations of the present study. Firstly, since we did not take pathologic biopsy of the liver, we can only report the abnormality of liver through ultrasonic and serum transaminase examination without pathologic analysis. Secondly, since serum levels of total adiponectin were assayed by ELISA, while we could not identify different forms of adiponectin. Thirdly, we could not confirm the accurate role of adiponectin in NALFD, further study is necessary to determine the natural disease progression and the role of adiponectin and other factors in the pathophysiology of NAFLD.

In summary, our data support the view that adiponectin plays a protective role in NAFLD in obese children, and that the measurement of adiponectin should be a part of the standard evaluation of the obese child and maybe help to evaluate the occurrence of NAFLD. Further longitudinal studies are required to determine the ratio of different forms of adiponectin and the role of adiponectin in the pathophysiology of NAFLD.

\section{Acknowledgments}

We thank all the children and their parents for participating in this research project. We thank Dr. Dong Guanping, Jiang Youjun, and Li Yun for their exceptional patient care and organization. We also thank Chen Liqin for her assay expertise. This work was supported by Zhejiang Science and Technology grants (2005C24001).

\section{References}

1. Takahashi N, Qi Y, Patel HR, Ahima RS (2004) A novel aminosterol reverses diabetes and fatty liver disease in obese mice. J Hepatol 41: 391-398.

2. Cortez-Pinto H, Camilo ME (2004) Non-alcoholic fatty liver disease/non-alcoholic steatohepatitis (NAFLD/ NASH): diagnosis and clinical course. Best Pract Res Clin Gastroenterol 18: 1089-1104.

3. Grant LM, Lisker-Melman M (2004) Nonalcoholic fatty liver disease. Ann Hepatol 3: 93-99.

4. Bugianesi E, Marzocchi R, Villanova N, Marchesini G (2004) Non-alcoholic fatty liver disease/non-alcoholic steatohepatitis (NAFLD/NASH): treatment. Best Pract Res Clin Gastroenterol 18: 1105-1116.

5. Angulo P, Alba LM, Petrovic LM, Adams LA, Lindor KD, Jensen MD (2004) Leptin, insulin resistance, and liver fibrosis in human nonalcoholic fatty liver disease. J Hepatol 41: 943-949.
6. Videla LA, Rodrigo R, Araya J, Poniachik J (2004) Oxidative stress and depletion of hepatic long-chain polyunsaturated fatty acids may contribute to nonalcoholic fatty liver disease. Free Radic Biol Med 37: 1499-1507.

7. Worda C, Leipold H, Gruber C, Kautzky-Willer A, Knofler M, Bancher-Todesca D (2004) Decreased plasma adiponectin concentrations in women with gestational diabetes mellitus. Am J Obstet Gynecol 191: 2120-2124.

8. Fasshauer M, Paschke R, Stumvoll (2004) Adiponectin, obesity, and cardiovascular disease. Biochimie 86: 779-784.

9. Higashiura K, Ura N, Ohata J, Togashi N, Takagi S, Saitoh S, Murakami H, Takagawa Y, Shimamoto K (2004) Correlations of adiponectin level with insulin resistance and atherosclerosis in Japanese male popu- 
lations. Clin Endocrinol (Oxf) 61:753-759.

10. Asayama K, Hayashibe H, Dobashi K, Uchida N, Nakane T, Kodera K, Shirahata A, Taniyama M (2003) Decrease in serum adiponectin level due to obesity and visceral fat accumulation in children. Obes Res 11: 1072-1079.

11. Steppan CM, Bailey ST, Bhat S, Brown EJ, Banerjee RR, Wright CM, Patel HR, Ahima RS, Lazar MA (2001) The hormone resistin links obesity to diabetes. Nature 409: 307-312.

12. Fujita H, Fujishima H, Morii T, Koshimura J, Narita T, Kakei M, Ito S (2002) Effect of metformin on adipose tissue resistin expression in $\mathrm{db} / \mathrm{db}$ mice. Biochem Biophys Res Commun 298: 345-349.

13. Degawa-Yamauchi M, Bovenkerk JE, Juliar BE, Watson W, Kerr K, Jones R, Zhou Q, Considine RV (2003) Serum resistin (FIZZ3) protein is increased in obese humans. J Clin Endocrinol Metab 88: 54525455.

14. Lee JH, Chan JL, Yiannakouris N, Kontogianni M, Estrada E, Seip R, Orlova C, Mantzoros CS (2003) Circulating resistin levels are not associated with obesity or insulin resistance in humans and are not regulated by fasting or leptin administration: cross-sectional and interventional studies in normal, insulin-resistant, and diabetic subjects. J Clin Endocrinol Metab 88: 48484856.

15. Beltowski J (2003) Adiponectin and resistin - new hormones of white adipose tissue. Med Sci Monit 9: RA55-61.

16. Roberts EA (2002) Steatohepatitis in children. Best Pract Res Clin Gastroenterol 16: 749-765.

17. Dixon JB, Bhathal PS, O'Brien PE (2001) Nonalcoholic fatty liver disease: predictors of nonalcoholic steatohepatitis and liver fibrosis in the severely obese. Gastroenterology 121: 91-100.

18. Loguercio C, De-Girolamo V, de-Sio I, Tuccillo C, Ascione A, Baldi F, Budillon G, Cimino L, Di Carlo A, Di Marino MP, Morisco F, Picciotto F, Terracciano L, Vecchione R, Verde V, Del Vecchio Blanco C (2001) Non-alcoholic fatty liver disease in an area of southern Italy: main clinical, histological, and pathophysiological aspects. J Hepatol 35: 568-574.

19. Nanda K (2004) Non-alcoholic steatohepatitis in children. Pediatr Transplant 8: 613-618.

20. Day CP (2004) The potential role of genes in nonalcoholic fatty liver disease. Clin Liver Dis 8: 673-691.

21. Hui JM, Hodge A, Farrell GC, Kench JG, Kriketos A, George J (2004) Beyond insulin resistance in NASH: TNF-alpha or adiponectin? Hepatology 40: 46-54.

22. Day CP (2004) The potential role of genes in nonalcoholic fatty liver disease. Clin Liver Dis 8: 673-691.
23. Feldstein AE, Werneburg NW, Canbay A, Guicciardi ME, Bronk SF, Rydzewski R, Burgart LJ, Gores GJ (2004) Free fatty acids promote hepatic lipotoxicity by stimulating TNF-alpha expression via a lysosomal pathway. Hepatology 40: 185-194.

24. Chachkhiani I, Gurlich R, Maruna P, Frasko R, Lindner $\mathrm{J}$ (2004) The postoperative stress response and its reflection in cytokine network and leptin plasma levels. Physiol Res [Epub ahead of print]

25. Pai JK, Pischon T, Ma J, Manson JE, Hankinson SE, Joshipura K, Curhan GC, Rifai N, Cannuscio CC, Stampfer MJ, Rimm EB (2004) Inflammatory markers and the risk of coronary heart disease in men and women. N Engl J Med 351: 2599-2610.

26. Ding WX, Yin XM (2004) Dissection of the multiple mechanisms of TNF-alpha-induced apoptosis in liver injury. J Cell Mol Med 8: 445-454.

27. Youssef WI, McCullough AJ (2002) Steatohepatitis in obese individuals. Best Pract Res Clin Gastroenterol 16: 733-747.

28. Marchesini G, Brizi M, Bianchi G, Tomassetti S, Bugianesi E, Lenzi M, McCullough AJ, Natale S, Forlani G, Melchionda N (2001) Nonalcoholic fatty liver disease: a feature of the metabolic syndrome. Diabetes 50: 1844-1850.

29. Pajvani UB, Du X, Combs TP, Berg AH, Rajala MW, Schulthess T, Engel J, Brownlee M, Scherer PE (2003) Structure-function studies of the adipocyte-secreted hormone Acrp30/adiponectin. Implications for metabolic regulation and bioactivity. $J$ Biol Chem 278: 9073-9085.

30. Waki H, Yamauchi T, Kamon J, Ito Y, Uchida S, Kita S, Hara K, Hada Y, Vasseur F, Froguel P, Kimura S, Nagai R, Kadowaki T (2003) Impaired multimerization of human adiponectin mutants associated with diabetes. Molecular structure and multimer formation of adiponectin. J Biol Chem 278: 40352-40363.

31. Tsao TS, Lodish HF, Fruebis J (2002) ACRP30, a new hormone controlling fat and glucose metabolism. Eur $J$ Pharmacol 440: 213-221.

32. Kobayashi H, Ouchi N, Kihara S, Walsh K, Kumada M, Abe Y, Funahashi T, Matsuzawa Y (2004) Selective suppression of endothelial cell apoptosis by the high molecular weight form of adiponectin. Circ Res 94: e27-31.

33. Pajvani UB, Hawkins M, Combs TP, Rajala MW, Doebber T, Berger JP, Wagner JA, Wu M, Knopps A, Xiang AH, Utzschneider KM, Kahn SE, Olefsky JM, Buchanan TA, Scherer PE (2004) Complex distribution, not absolute amount of adiponectin, correlates with thiazolidinedione-mediated improvement in insulin sensitivity. J Biol Chem 279: 12152-12162. 